\title{
Impact of Small Scale Irrigation Development on Farmers' Livelihood Improvement in Ethiopia: A Review
}

\author{
GEBRE GIDEY \\ Department of Natural Resource Management, Dambi Dollo University, Ethiopia
}

\begin{abstract}
This review aims to illustrate the impact of small scale irrigations on farmers' livelihood improvement in Ethiopia. It discusses the Ethiopian small scale irrigation development, categories and it impact on farmers' livelihood improvement. The Ethiopian government has made a huge investment to develop small-scale irrigation schemes, and plans to enhance the recent level of irrigation infrastructure three fold by the end of 2020 to solve the household food insecurity problem of smallholder.Small scale irrigation is prioritized as one of the best alternatives for sustainable livelihood improvement, transformation growth and rural poverty alleviation in the country .It has multi-dimensional impacts on the living development of the rural people. It benefits smallholders in the course of crop diversification and intensification, employment opportunities, livestock production, credit services and increasing household incomes. Therefore, this review is important for understanding what was done in the past and what is going on now in improving farmers' livelihood through small scale irrigation development in Ethiopia. Keywords: Small scale irrigation, Livelihood improvement, Ethiopia
\end{abstract}

DOI: $10.7176 / \mathrm{JRDM} / 62-02$

Publication date: January $31^{\text {st }} 2020$

\section{INTRODUCTION}

Ethiopia is faced with a compound poverty, which is broad and deep (MoFED 2002).It has been a food shortfall country for a number of decades (FAO 2001).It was claimed that the country cannot guarantee food security for its population with rain fed agriculture alone without supplementary contribution of irrigation (Tesfaye et al. 2008). Accordingly, the government of Ethiopia has geared up a water sector development program to be implemented in 15 years between 2002 and 2016. This program assigned an important role to the development of irrigation in the country for food production (Tesfaye et al. 2008). It has major magnitude to raise production and productivity to attain food self-sufficiency and guarantee food security at household level in particular and the country in general ( Nahusenay and Madhun 2015).

Consequently, the Ethiopian government has made a huge investment to develop small-scale irrigation schemes, and plans to enhance the recent level of irrigation infrastructure three fold by the end of 2020 to solve the household food insecurity problem of smallholder farmers (Haile and Kassa 2015). Small scale irrigation is prioritized as one of the best alternatives for sustainable livelihood improvement, transformation growth and rural poverty alleviation in the country (Dereje and Desale 2016). It has multi-dimensional impacts on the living development of the rural people (Dereje and Desale 2016). It benefits smallholders in the course of crop diversification and intensification, employment opportunities, livestock production, credit services and increasing household incomes (Asayehegn et al. 2011).

Several studies indicated a strong linkage between small scale irrigation development and poverty reduction (Nahusenay and Madhun 2015), and believed that, small-scale irrigation is a valuable method to increase food production and poverty alleviation (Fanadzo 2012). Among the several, Hussain et al. (2006) made a qualified analysis of small scale irrigation impact on poverty reduction, and argued that irrigation alleviate poverty both directly and indirectly, where the direct impacts are realized through labor and land intensification effect that eventually translates to improved productivity, employment and income while the indirect impact is realized through improved local economy and enhanced welfare at universal level (Asayehegn et al. 2011).

However, simply providing small scale irrigation infrastructure to farmers is not an assurance that farmers' poverty and food insecurity are being reduced. In addition to that, permitting socio-economic facilities, such as access to roads, markets, and suggestion about innovations must be provided to farmers to involve in small scale irrigation development and assure food security and poverty alleviation (Desta and Almaz 2015). Therefore, this review is important for understanding what was done in the past and what is going on now in improving farmers' livelihood through small scale irrigation development in Ethiopia.

\section{SMALL SCALE IRRIGATION IN ETHIOPIA: DEVELOPMENT AND CATEGORIES}

\subsection{Development}

In Africa, irrigation is incredibly old practice, dating back to the most primitive civilizations of humankind (FAO 2001). Similar to the other African countries, irrigation in Ethiopia is eras back several centuries, and continues to be an integral part of Ethiopian agriculture. Farmers had been practicing by diverting water from rivers in the dry 
season for subsistence food crops production (FAO 2001). But, the modern irrigation began in the 1960s through secret and government owned schemes in the middle Awash Valley (Kidane et al. 2014), with the objective of producing industrial crops on large scale basis (Dereje and Desale 2016).

But, the modern small scale irrigations started in the early 1980s following the major drought, which caused crop failures and consequent of devastating famine of 1984/85. After that starvation, the government began to focal point on the potential of small scale irrigation and started promoting farmer and community based small scale irrigation by given that aid and support to the local communities for rehabilitating and improvement traditional schemes as food security improvement strategy (Habtamu 1990).

Since 1994, significant number of small scale irrigation schemes has being developed and modernize existing traditional irrigation schemes have been implemented (Tesfa 2011). Currently, a study by Ministry of Water, Irrigation and Electricity set plan from 2002-2016 identified that, there are 127, 000 irrigation schemes in the different regional states of Ethiopia, from those irrigation schemes, 75\% are small scales (Amede 2014).

\subsection{Categories}

In the context of Ethiopia, Small scale irrigation refers to smallholder farms with the size of scheme usually about 200 hectares or less (Dereje and Desale 2016). Examples of small scale irrigation scheme include hand-dug wells, shallow wells, spate, river diversions and other traditional methods (Haile and Kassa 2015). There are two major categories of small scale irrigation schemes, the modern and the traditional schemes. The traditional small scale irrigation schemes in Ethiopia are understood up to 100 ha and modern schemes up to 200 ha (Hagos et al. 2010). The modern have relatively permanent structure and improved water control system, and are mostly constructed by either the government or NGOs (Mosissa and Bezabih 2017), while the traditional are constructed by the local community using local materials. There is always a need to reconstruct every year after the end of the rainy season (Mosissa and Bezabih 2017). Both traditional and modern small scale irrigation schemes are farmer-managed irrigation systems with their own local leadership of water users' associations or irrigation cooperatives (Mosissa and Bezabih, 2017). Usually farmers have the majority controlling influence, which they can operate and maintain effectively with help of government or NGOs technical and material support (Desta and Almaz 2015).

\section{IMPACT OF SMALL SCALE IRRIGATION ON FARMERS' LIVELIHOOD IMPROVEMENT IN ETHIOPIA}

\subsection{Impact on Livestock Production}

Livestock are an important asset in many parts of Ethiopia, and farmers' produce large livestock size using small scale irrigation schemes in rural areas of the country (Mintesnot et al. 2004). Comparison study on farmers' livestock number before and after irrigation developments at three small scale irrigation schemes(La'elay Wukro, Mai-Nigus and Korir) in Tigray region(Ethiopia) showed that, a significant livestock number increment after the irrigation schemes development( Mintesnot et al. 2004).

Similar studies in three small scale irrigation schemes(Sanka ,Jrsa and Gedober) and North Gondar zone small scale irrigation users of Amhara region(Ethiopia), reported that irrigators have large livestock number(Dereje and Desale 2016; Agerie 2016). Likewise studies, in Ketar and, Godino and Filtino small scale irrigation schemes (Oromia Region, Ethiopia), showed that livestock ownership by irrigation users is almost double than that of nonusers (Tefera and Cho 2017; Tesfaye et al. 2008).

This shows that, irrigation user households have large number of livestock as compared to non-users (Figure 1). This is due to access of water from the irrigation canals and animal feed. However, unlike irrigators, nonirrigators have insufficient animal feed resources, the livestock of the non-irrigators' are necessarily sold to get food. 


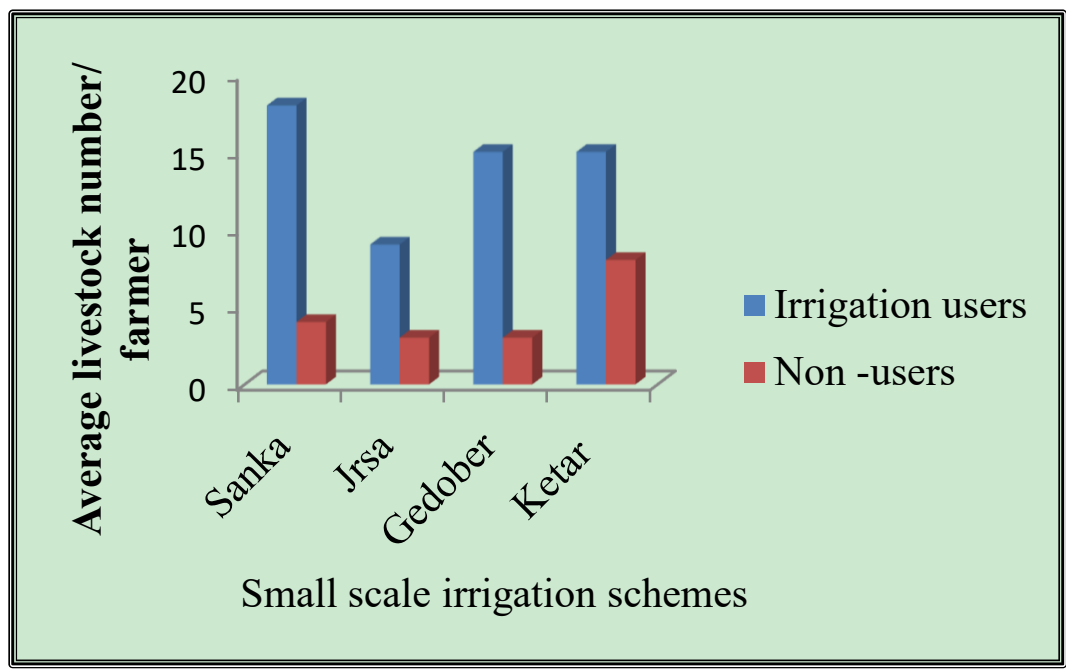

Figure 1: Livestock number comparison between irrigation users and non-users in Ethiopia (Dereje and Desale 2016; Tefera and Cho 2017)

\subsection{Impact on Crop Diversification and Intensification}

Small scale irrigation in Ethiopia has great important to grow multiple crops at a time in farm plot (Eshetu 2010; MoA 2011) (Figure 2). Likewise, Agerie (2016) stated that irrigation users in North Gondar Zone (Amhara region) produce different kinds of crops, vegetables and fruits using small scale irrigation schemes at single farm land. Similarly, a time series (1992-2004) study in the Arab countries indicated that small scale irrigation enabled farmers to grow multiple crops two to four times a year (Singh et al. 2009).

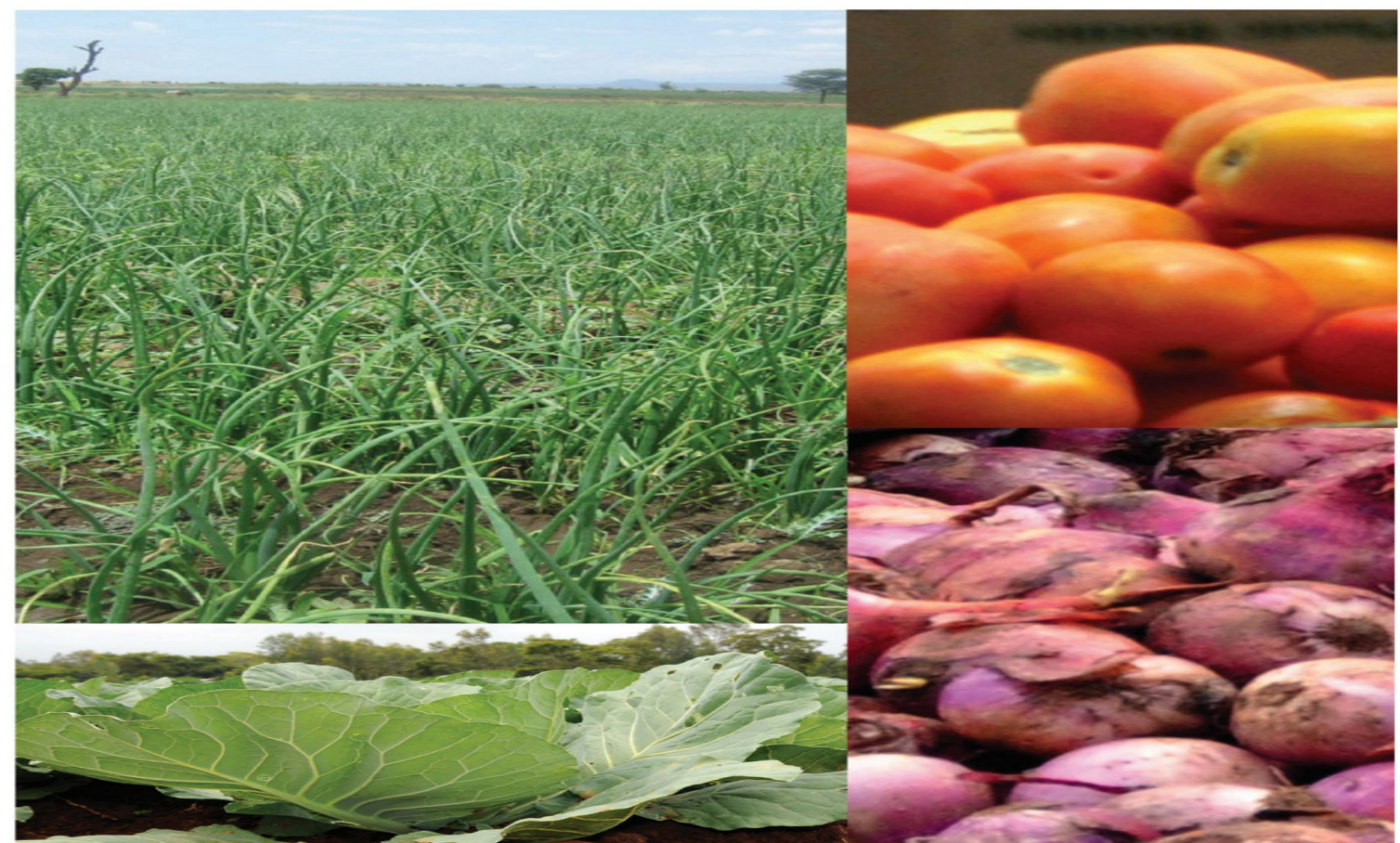

Figure 2: Diversified product types (MoA 2011)

Development of small- scale irrigation scheme also led to raise cropping intensity per year and increase production by supplementing the rain fed production (Tesfaw 2018). It also enables farmers to grow crops more than once a year, for poverty reduction and promotion of sustainable rural livelihoods in Ethiopia (Tesfaye et al. 2008). A study conducted by REST (2003) in Gereb Meheze irrigation scheme (Tigray regional state) reflects that, all farmers in the irrigation scheme produce crops two times a year after development of the irrigation scheme; un like before the irrigation scheme development they used to grow crops only once a year (Table1). 
Table1. Crop production before and after irrigation in Gereb Meheze irrigation users, Ethiopia (REST 2003)

\begin{tabular}{|l|l|l|}
\hline Before irrigation & \multicolumn{1}{|c|}{ After irrigation } \\
\hline Teff & Wet season & \multicolumn{1}{|c|}{ Dry season } \\
Wheat & Teff & Maize \\
Wheat & Wheat & Pepper \\
Barley & Wheat & Onion \\
Pea & Barley & Tomato \\
\hline
\end{tabular}

\subsection{Impact on Employment Opportunity}

Small scale irrigation in Ethiopia is not only used for enhancing farmer's livestock and crop production, but also it generates employment opportunity to some members of the family especially to wife and children of the irrigation users, and the non-irrigation users; the daily laborers work in the irrigation farms of the irrigation users (Tefera and Cho 2017). Irrigator farmers employed different workers at different levels of activity with different wages (Agerie (2016). Such as, land preparation, weeding, adding of chemicals, watering, harvesting and transporting and storing of the product (Dereje and Desale 2016).

A similarly in South Africa irrigation schemes have increased employment opportunities and increased rural wage rates (Fanadzo 2012). And, a study in China in 2005 showed that employment and wage rates were higher in irrigated areas with a 50\% than rainfed (Huang et al. 2006).

\subsection{Impact on Extension and Credit services}

Extension service is the advice, training and demonstration related to crop production and productivity, and management (Agerie 2016).A study result (Agerie 2016) in North Gondar Zone (Amhara region), revealed that $86 \%$ of the irrigation users get extension service while the non-users were $16 \%$. This indicates that there is direct relationship between access to irrigation and extension service (Tefera and Cho 2017).

Any form of credit (cash or other) is an important organizational service for rural people for input for purchase and to adopt new technology. A Study on Ketar small scale irrigation scheme in Oromia region indicates that $67 \%$ of the irrigation users get credit service while the non-users were 45\% (Tefera and Cho 2017) (Figure 3). Similarly, in North Gondar Zone, $80 \%$ of the irrigation users were access to credit while the non-users were $32 \%$ (Agerie 2016) (Figure 3). Even if the government of Ethiopia is given equal credit access to all farmers, the irrigation users have better credit access compared to none users. The factor that affects the non-users to credit access is shortage of money for repayment (Agerie 2016).

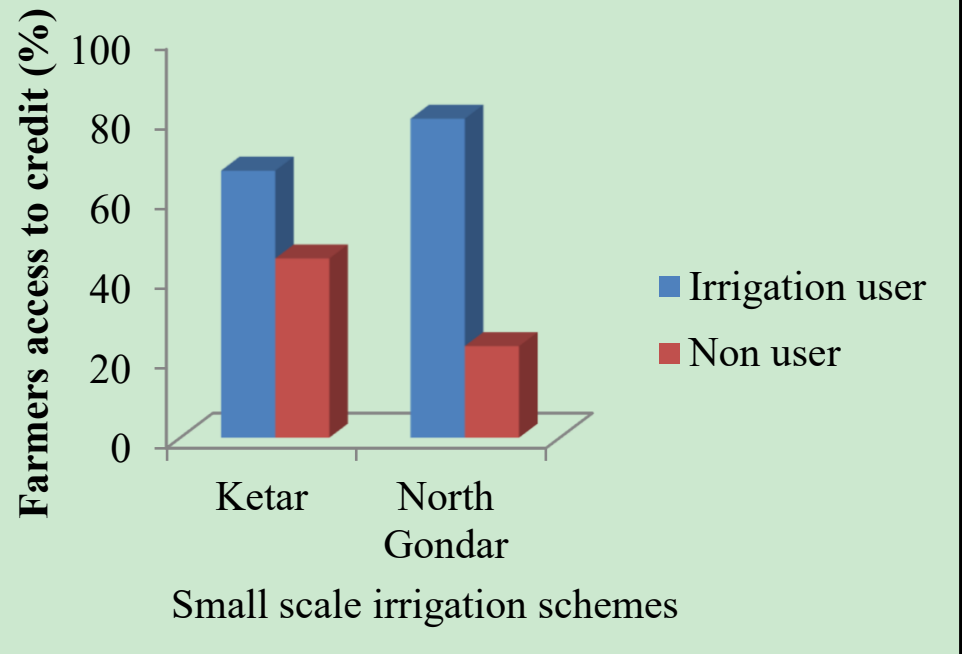

Figure 3: Credit accessibility comparison between irrigation users and non-users in Ethiopia (Tefera and Cho 2017; Agerie 2016)

\subsection{Impact on Farmers' Income}

A study in Ethiopia found that irrigation is a significant determinant of Farmers' income (World Bank 2012) A case study from three irrigation schemes (La'elay Wukro, Mai-Nigus and Korir) in Tigray region indicated that the farmers increase their annual income around $40 \%$ after the irrigation scheme development comparing to before irrigation intervention (Mintesnot et al. 2004). Similar study from three irrigation schemes (Sanka, Jrsa and 
Gedober) in Amhara region showed significant change of farmers' income after irrigation development (Figure $4 a)$. The average result from the case study of the irrigation schemes indicated that annual income increase around $50 \%$ after the irrigation scheme development comparing to before irrigation intervention(Dereje and Desale 2016).

And, when compare the income status of the irrigation users and non-users in those irrigation schemes area, using irrigation has a great role in improving income of farmers. Likewise study from Ketar small scale irrigation Scheme (Oromia Region) indicated that ,there is significant difference between the two groups in their mean income(Figure 4b); and irrigation users are in better position (Tefera and Cho 2017). Overall in Ethiopia, the average income of irrigator farmers' is almost double of that of the non-irrigator farmers' (Zewelde et al 2015).

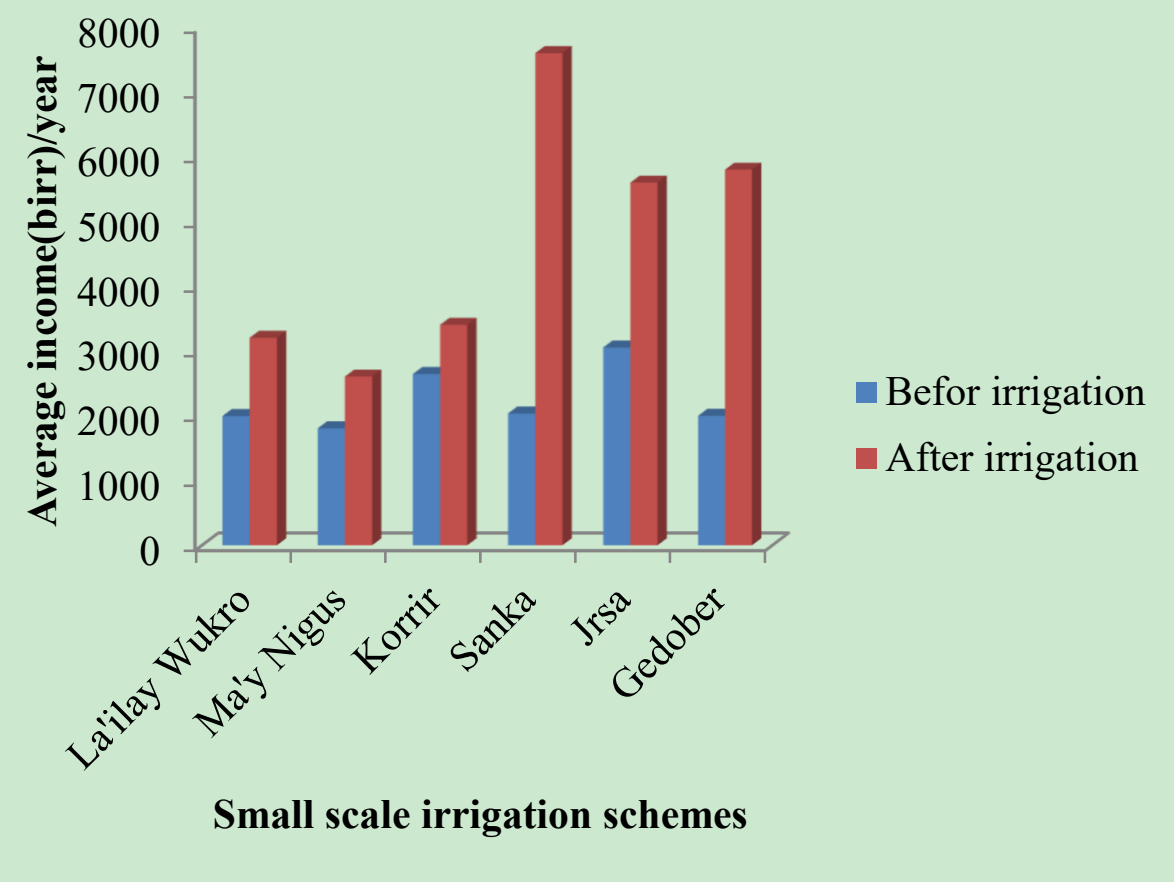

Figure 4a: Annual farmers' income comparison between before irrigation development and after irrigation intervention in Ethiopia (Dereje and Desale 2016; Mintesnot et al. 2004)

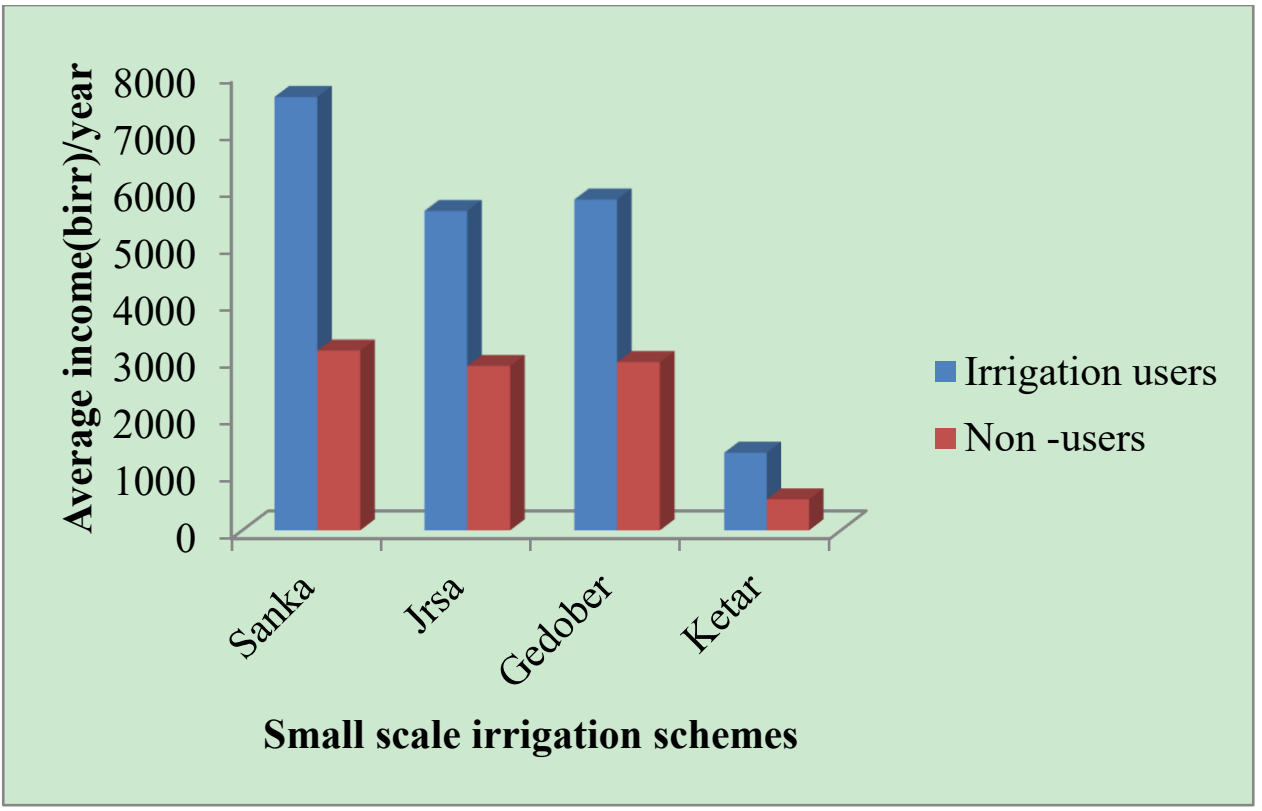

Figure 4b: Annual farmers' income comparison between irrigation users and non-users in Ethiopia (Dereje and Desale 2016; Tefera and Cho 2017) 


\subsection{Impact on Food self- sufficiency and Food security}

Irrigation in Ethiopia improved yields per capita hectare, income and food security (Hagos et al. 2009). Small scale irrigation scheme development is one of the major approaches used to alleviating the difficult of food insecurity. One main implication is that make sure every farmer has the ability of either producing or purchasing its food requirement (Zewelde et al. 2015). The study by IFAD (2005) indicated that, in Ethiopia the construction of small scale irrigation schemes have resulted in increased income in Oromia and Southern Nations, Nationalities and People region, and the hungry months reduced from 6 to 2 months because of the use of small scale irrigation. Similarly, from the case studies of the three irrigation schemes in Tigray region(Figure 5a) indicated that even if the farmers are not food self-sufficient the whole year after the development of the irrigation schemes, most of them feed themselves longer than before the irrigation interventions (Mintesnot et al. 2004). Similarly, case study on food security situation comparison between irrigation users and non-users in Oromia Region small scale irrigation scheme (Figure 5b) indicated that, irrigation users were in better position than that of non-users, bout $65 \%$ of irrigation users are food secured where this is only $29 \%$ for non-users (Tefera and Cho 2017).

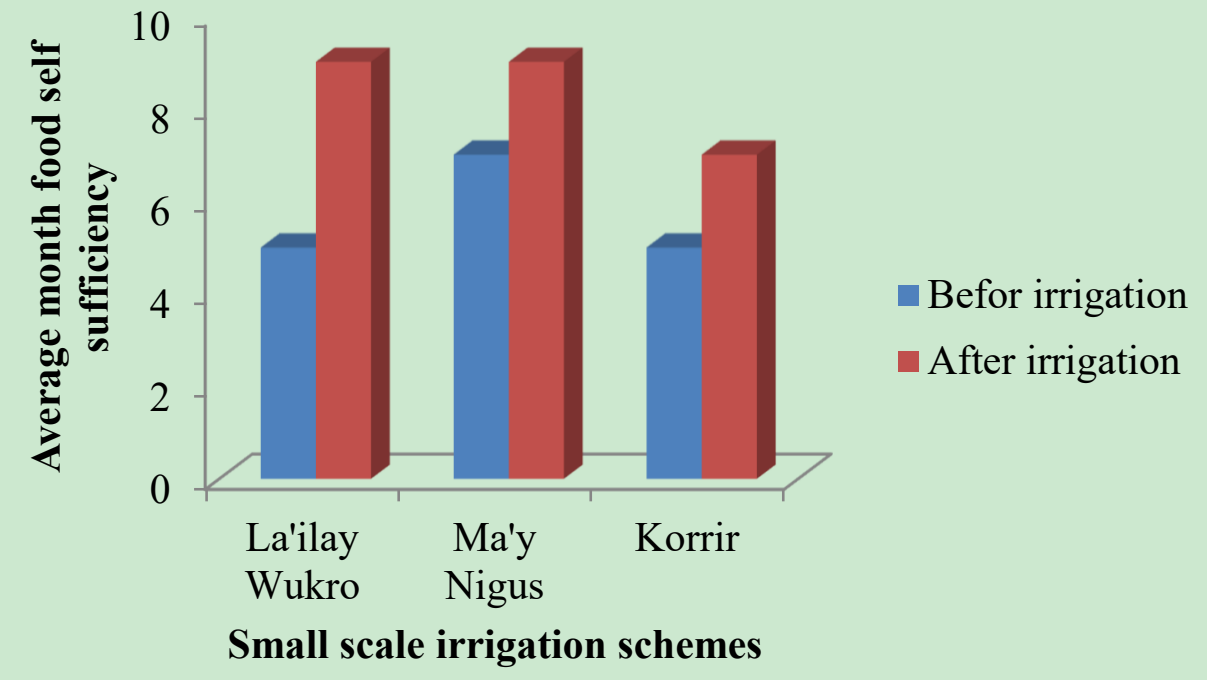

Figure 5a: Farmers' food self-sufficiency comparison between before irrigation development and after irrigation intervention in Tigre region, Ethiopia (Mintesnot et al., 2004)

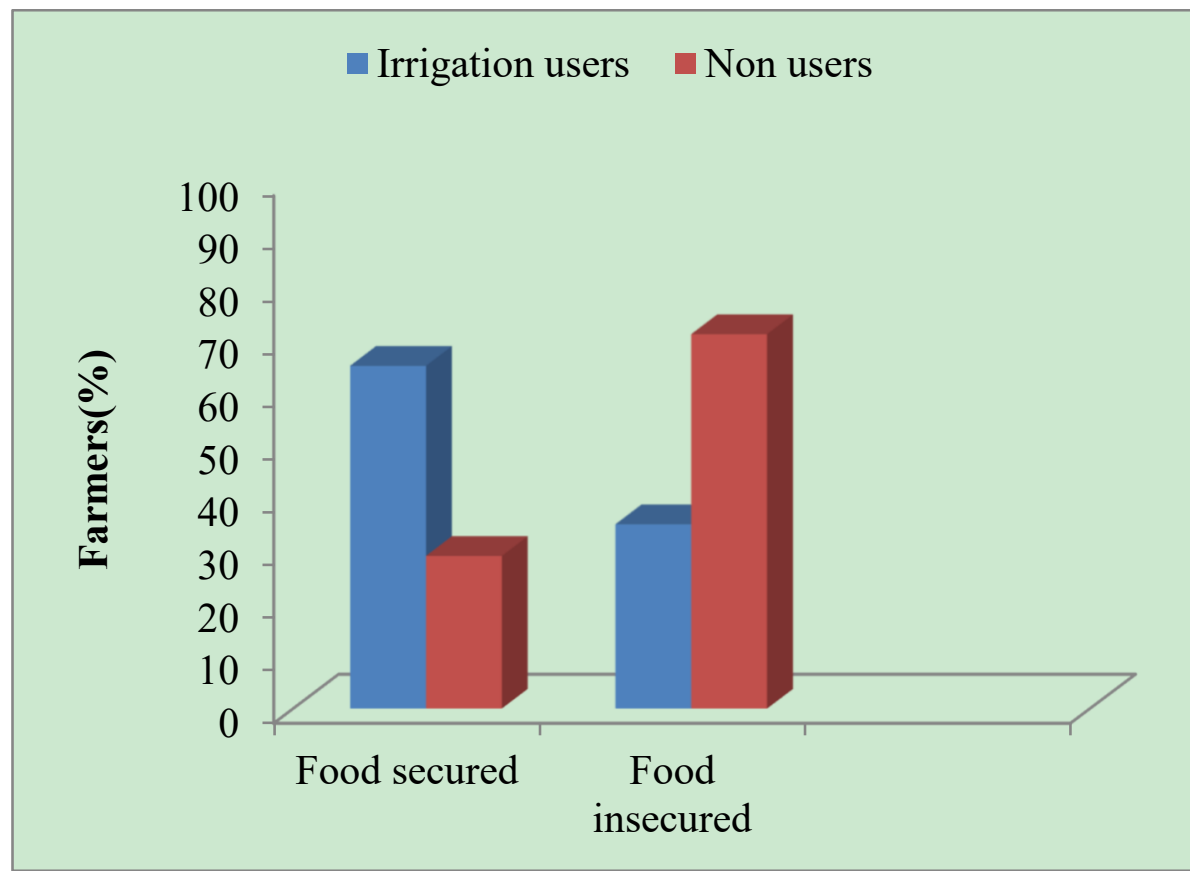

Figure 5b: Farmers' food security situation comparison between irrigation users and non-users in Oromia region, Ethiopia (Tefera and Cho 2017). 


\subsection{Farmers' Livelihood Success through Small Scale Irrigation Development}

Five key dimensions, includes production, income, employment, food security, and other social impact in which small scale irrigation schemes can donate to reduce rural poverty and improve farmers' livelihood(Huang et al. 2006). Similar studies show that, small scale irrigation in developing countries was counted to intensify production and provide jobs to the poor, which in turn enable people to consume own food instead of depending on food aids from the government, increase wealth and keep good health status (FAO 2011).

Likewise in Ethiopia, based on the various studies conducted in different regions of the country, small scale irrigations developments have a marked impact on farmers' livelihood improvement (IFAD 2005). The immediate outcomes of small scale irrigation interventions include, increase livestock production, crop diversification and intensification, employment opportunity, access to extension and credit services (Woldeab, 2003; Mintesnot et al. 2004; Tefera and Cho 2017).

These outcomes in turn contribute to increase farmers' income and assured food security (Dereje and Desale 2016; Tesfaye et al. 2008). Then, all these and other outcomes of small scale irrigation developments joint have the capacity to attain livelihood improvement in particular and poverty reduction in general (Mosissa and Bezabih 2017) (Figure 6).

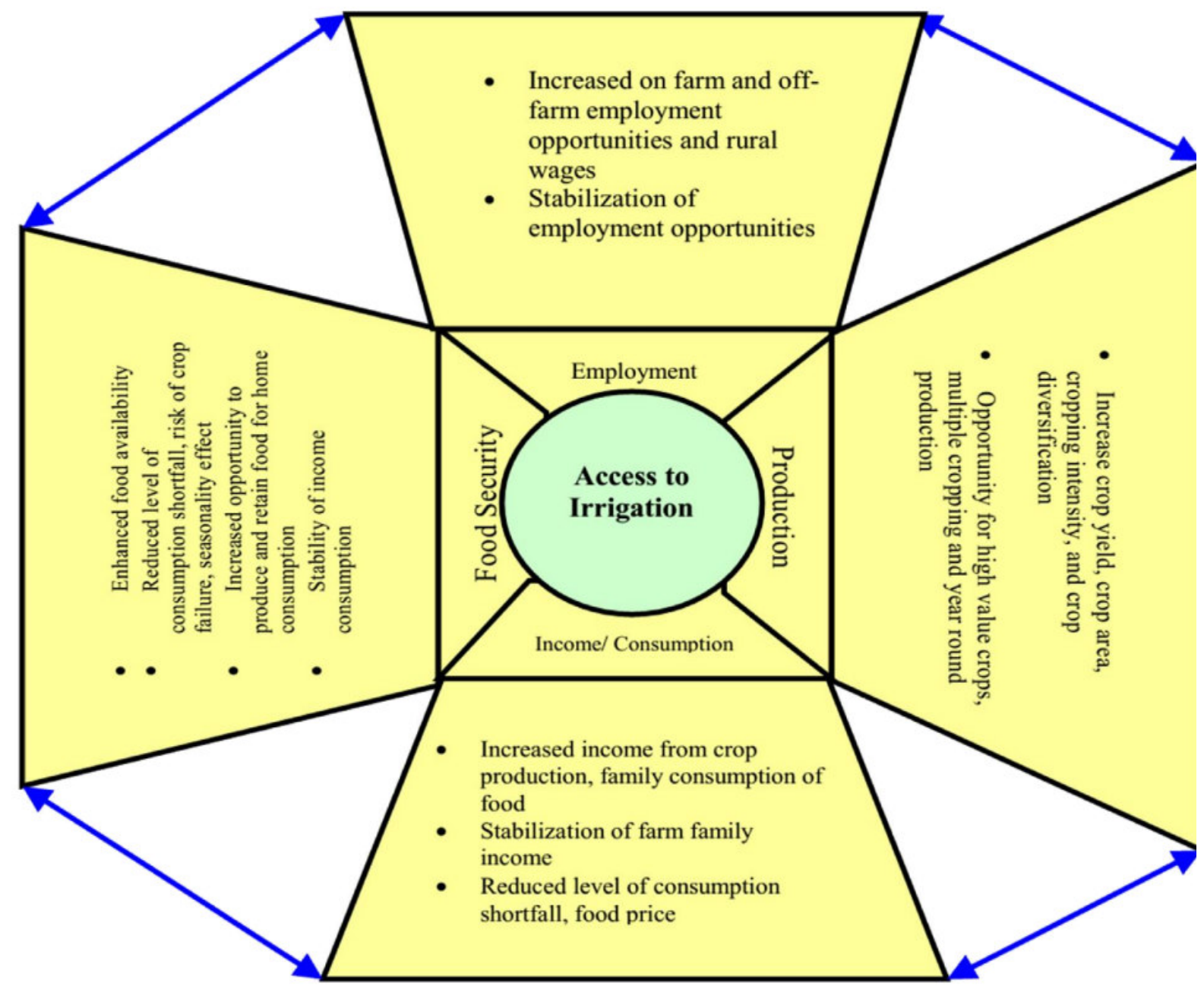

Figure 6: Interlink between Irrigation and Livelihood Improvement (Woldeab 2003)

\section{CONCLUSION}

Reviewing of small scale irrigation development creates the opportunity for farmers to diversify their income and reduced their dependency on rain fed agriculture that would like to improve food sufficiency status than before the development of small scale irrigation practices. Small scale irrigations in Ethiopia have many impacts on the livelihood improvement of the rural people. Either directly or indirectly it changes farmers' mode of life.

Through crops diversification and intensifications, livestock production, employment opportunity, income increment and food security. Evidences indicate that farmers are more food secured after irrigation intervention compared to before irrigation development, and irrigation user farmers are getting a better income and food secured than non-users. 


\section{REFERENCE}

Agerie N (2016). Determinants of Smallholder Rural Farm Households' Participation in Small Scale Irrigation and Its Effect on Income in North Gondar Zone Amhara Regional State, Ethiopia. International journal of innovative Research and Development.Vol,5(6)

Amede T (2014). Technical and institutional attributes constraining the performance of small- scale irrigation in Ethiopia', Water Resour. Rural Dev.

Asayehegn K,Yirga Ch, Rajan S (2011). Effect of small-scale irrigation on the income of rural farm households: The case of Laelay Maichew District, Central Tigray, Ethiopia. Journal of Stored Products and Postharvest Research Vol. 2(10), pp. $208-215$

Dereje M, Desale K( 2016). Assessment of the Impact of Small-Scale Irrigation on Household Livelihood Improvement at Gubalafto District, North Wollo, Ethiopia. Journal of Agriculture, 6, 27

Desta D, Almaz B (2015). Review on Impact of Small Scale Irrigations in Household Food Security in Ethiopia. J. Econ. Sustain. Dev.6(21):62-70

Eshetu S, Belete B, Goshu D, Kassa B, Tamiru D, Worku E, Lema Z, DelelegnA, Tucker J, Abebe Z(2010). Income Diversification through Improved Irrigation in Ethiopia: Impacts, Constraints and Prospects for Poverty Reduction. Evidence from East Harerghe Zone, Oromia Region, Ethiopia. Overseas Development Institute, Research-Inspired Policy and Practice Learning In Ethiopia and the Nile Region (Ripple), Working Paper 14, Ethiopia.

Fanadzo M (2012). Revitalisation of Smallholder Irrigation Schemes for Poverty Alleviation and Household Food Security in South Africa: A Review. African Journal of Agricultural Research, Vol. 7(13), PP. 1956-1969.

FAO (2011). The State of Food Insecurity in the World: How Does International Price Volatility Affect Domestic Economies a Food Security? ISBN 978-92-5-106927-1, FAO, Rome. http://www.fao.org

FAO (Food and Agricultural Organization of the United Nations) (2001). The state of food and agriculture. World Review Part I: 18-20. Rome. Italy

Habtamu G (1990). Problems and Constraints in the Study, Construction and Management of Small scale Irrigation Projects, Paper No. S2-6. Presented at the National Irrigation Policy and Strategy Workshop, Addis Ababa.

Hagos F, Makombe G, Namara R, Awulachew S (2009). Importance of Irrigated Agriculture to the Ethiopian Economy: Capturing the Direct Net Benefits of Irrigation, IWMI, Working Paper 128, ISSN 1026-0862, Addis, Ethiopia.

Haile G, Kassa K ( 2015 ). Irrigation in Ethiopia: A review. Academia Journal of Agricultural Research 3(10): 264-269

Huang Q, Rozelle S, Lohmar, B, Huang J,Wang J (2006). Irrigation, Agricultural Performance and Poverty Reduction in China. Food Policy, Vol. 31, PP. 30-52

Hussain M, Hussain Z, Ashfag M (2006). Impact of Small Scale Irrigation Schemes on Poverty Alleviation in Marginal Areas of Punjab, Pakistan. International Research Journal of Finance and Economics, Issue 6, PP. 193-200.

IFAD (International Fund for Agricultural Development) (2005) Special country program phase II. Interim evaluation report number 1643-ET, Ethiopia

Kidane D, Mekonnen A, Teketay D (2014). Contributions of Tendaho Irrigation Project to the improvement of livelihood of Agro pastoralists in the Lower Awash Basin, Northeastern Ethiopia. Ethiop. J. Res. Innov. Foresight .Vol. 6, 1-19.

Mintesinot B, Mohammed A, Atinkut M, Mustefa Y(2004). Preliminary Report On Community Based Irrigation Management in the Tekeze Basin: Impact Assessment, a case study on three small-scale irrigation schemes (micro dams) .

MoFED (Ministry of Finance and Economic Development) (2002). Sustainable development and poverty reduction program, pp. 1-87. Addis Ababa, Ethiopia

Mosissa T, Bezabih, B (2017). Review on participatory small-scale irrigation schemes and small-scale rainwater harvesting technology development and its contribution to household food security in Ethiopia. International Journal of Water Resources and Environmental Engineering, Vol. 9(3), pp. 54-63

Nahusenay T, Madhun P (2015). Opportunities and Challenges of Small-Scale Irrigation and Its Implications for Livelihood Improvement: The Case of Tigray Regional State, Northern Ethiopia. Journal of Business Management \& Social Sciences Research, volume 4, No.4.

Relief Society of Tigray (REST, 2003). Irrigation Development in Tigray part of the Tekeze Basin. Planning Work shop

Singh A, Rahman A, Sharma S, Upadhyaya U, Sikka A (2009). Small Holders' Irrigation Problems and Options. Water Resource Management, Vol. 23, PP. 289-302

Tefera E, Cho B ( 2017). Contribution of Small Scale Irrigation to Households' Income and Food Security: Evidence from Ketar Irrigation Scheme, Arsi Zone, Oromiya Region, Ethiopia. African Journal of Business 
Management, Vol. 11(3), pp. 57-68

Tesfa W (2001). Impact of Small Scale Irrigation on Socio-Economic Development in Dewa Cheffa Woreda, Oromia Zone of the Amhara National Regional States. MSc. Thesis, Addis Ababa University, Addis Ababa, Ethiopia

Tesfaw M (2018) Small Scale Irrigation Development. Irrigat Drainage Sys Eng 7: 206. DOI: 10.4172/21689768.1000206

Tesfaye A, Bogale A, Namara E, BachaD (2008). The impact of small-scale irrigation on household food security: The case of Filtino and Godino irrigation schemes in Ethiopia. Irrig Drainage Syst ,22:145-158

Woldeab T (2003). Irrigation practices, state intervention and farmers life-worlds in drought-prone Tigray.Dissertation, Wageningen University

World Bank (2012). Ethiopia Country Brief, the World Bank Group. Washington DC: The World Bank.

Zeweld W, Guido Van Huylenbroeck, Assefa Hidgot, M. G. Chandrakanth, Stijn Speelman (2015). Adoption of Small-Scale Irrigation and its Livelihood Impacts in Northern Ethiopia. Jornal of Irrigation and Drainage 